\title{
Evaluation of the Efficiency of Duckweeds, Lemna sp. and Spirodela sp., in the Treatment of Tilapia Effluents
}

\author{
Itzel Galaviz-Villa ${ }^{1}$, Cinthya Sosa-Villalobos ${ }^{1}$, Alicia García-Sánchez ${ }^{1}$, Ma. Refugio Castañeda-Chavez ${ }^{1}$, \\ Fabiola Lango-Reynoso ${ }^{1} \&$ Isabel Amaro-Espejo ${ }^{1}$ \\ ${ }^{1}$ Division of Graduate and Research Studies, Technological Institute of Boca del Río, Veracruz, México \\ Correspondence: Cinthya Sosa-Villalobos, Division of Graduate and Research Studies, Technological Institute \\ of Boca del Río, Km. 12 Carretera Veracruz-Córdoba. C.P. 94290, Boca del Río, Veracruz, México. Tel: \\ 52-229-986-2828 ext. 113. E-mail: ca.sosavi@gmail.com
}

Received: September 21, 2016

Accepted: October 26, 2016

Online Published: November 15, 2016

doi:10.5539/jas.v8n12p188

URL: http://dx.doi.org/10.5539/jas.v8n12p188

\begin{abstract}
Farming aquatic plants can be used as an alternative in the treatment of effluents from aquaculture production units and in turn, in the production of biomass plant for feeding terrestrial and aquatic organisms. This research aims to evaluate the efficiency of duckweeds Spirodela sp. and Lemna sp. in the treatment of tilapia effluents (Oreochromis niloticus). The experiment was performed in triplicate and was conducted under natural environmental conditions within the facilities of the Laboratory of Applied Aquaculture Research (LAAR) of the Technological Institute of Boca del Río (ITBOCA). Each treatment contained 230 liters of effluent in each tube, with a water column of $40 \mathrm{~cm}$ and a seeding density of $400 \mathrm{~g} / \mathrm{m}^{2}$ of vegetative biomass. The evaluation of the efficiency of Spirodela sp. and Lemna sp., in the removal of dissolved nutrients, was performed in 7 monitoring times; 12, 24, 36, 48, 72, 96 and $120 \mathrm{~h}$. The results showed an efficiency in nutrient removal at $120 \mathrm{~h}$ of 75,74 and $66 \%$ of $\mathrm{N}^{-\mathrm{NH}_{3}} ; 96,92$ and $75 \% \mathrm{~N}-\mathrm{NO}_{2} ; 93,88$ and $75 \% \mathrm{~N}-\mathrm{NO}_{3} ; 75,72$ and $64 \% \mathrm{~N}-\mathrm{NTK} ; 73,60$ and $58 \%$ of N-org., and 73, 63 and $68 \%$ of P. On the other hand, the removal of TSS and BOD5, during the first $24 \mathrm{~h}$, was $83,54,58 \%$ and $65,59,33 \%$, in the treatments. The efficiency in nutrient removal of both duckweeds, showed that both plants can be used in the treatment of effluents, being a sustainable and economical alternative for the aquaculture industry.
\end{abstract}

Keywords: phytoremediation, aquatic plants, aquaculture effluents

\section{Introduction}

One of the main constraints on aquaculture production is the high concentration of nutrients that are generated as a result of the excretions of fish, the provided food and other inputs used to control crop (Tacon \& Foster, 2003). Currently, the development model most used in Aquaculture Production Units (APU) is the intensive system, which makes the activity increasingly dependent on inputs such as; balanced food, electricity, hormones, antibiotics, etc. (Espinosa \& Bermudez, 2012).

In the state of Veracruz, most of the aquaculture production units of tilapia discharge their effluents directly, without previous treatment into bodies of surface water becoming a source of pollution for the aquatic environment (Palomarez-García, 2010). These effluents include uneaten feed, metabolic excretions, feces, dead fish and organic and inorganic solid waste. If the flow of these compounds, into the environment exceeds the assimilative capacity of ecosystems; it could cause severe impacts, both in the water column and in benthos, such as; eutrophication, oxygen depletion and alteration of local biodiversity (IUCN, 2007). The degree of environmental impact is straightly related to the production system used. These systems are: extensive, semi-intensive and intensive. As the system is intensified, a greater number of inputs and raw materials are used (Flores, González, \& Prado, 2007).

The environmental impact of aquaculture is an issue of global dimensions; freshwater aquaculture raises nutrient loading of river systems, which probably will intensify in the future. Much of the environmental impact of aquaculture is derived from the sum of individual farms. Although, environmental impact assessment and licensing and certification systems are required for individual intensive and for large-scale farms. There have not been approaches based on mitigation, nor management measures that collectively cover the overall impact of 
small farms. Some farms have an impact that affects their own culture systems, such as; generating hypoxia, fish kills or stress, or by creating conditions that favor the spread of disease (FAO, 2014).

Production of aquatic macrophytes in aquaculture effluents is considered an alternative for reducing large volumes of nutrients discharged into water and soil of national assets. These macrophytes are characterized by being highly productive and present an accelerated growth factor that has caused the research being directed toward its control, with emphasis on its eradication; however, in many developing countries, this vegetation is used as feed for farm animals. Due to its high productivity it generates excellent crops. Besides, they do not require most of the agricultural work, or the purchase of inputs such as seeds and fertilizers (Pacheco, 2009).

Ecosystems dominated by aquatic macrophytes are considered as the most productive in the world. Aquatic plants have the ability to assimilate nutrients and create favorable conditions for microbial decomposition of organic matter. For this reason, they are known as self-purifying for aquatic environments and are used in the treatment of wastewater (Brix \& Schierup, 1989; Pardo, 2006; Miranda \& Quiróz, 2013). Macrophytes of the Lemnaceae family have shown great ability in the assimilation of nutrients. Under optimal growth conditions, such as nutrient availability, light and optimal water temperature, can double its biomass every two or three days. And achieve protein content between $15 \%$ and $45 \%$, because they assimilate large amounts of nitrogen mainly in ammonium form and phosphorus in orthophosphate form. When used for the treatment of wastewater, they generate high quality biomass, because the ammonium is converted directly into protein. Among the potential uses of aquatic plants, we can refer to its operation as feed for cattle, sheep and pigs. They are used through the ensiling and drying process, then mixed with other feed; in feed for aquaculture production, in obtaining fertilizers, pulp or paper pulp production, for biological purification of wastewater and in the production of biofuels (Oron, 1994; Lallana, 1997; Zetina, 2010).

According to Troell et al. (2005) comprehensive methods of biotransformation, besides bringing ecological and social benefits, allow additional production of food without other input costs. For this, it is necessary to perform carefully planned scientific studies to prove that aquaculture is a production alternative with great potential for sustainable growth (FAO, 2003; Pardo, 2006). This research project aims to evaluate nutrient removal from tilapia effluents culture using aquatic macrophytes, Spirodela sp. and Lemna sp., as an alternative in effluents treatment and as protein production for supplementary feeding of their crops.

\section{Methods}

The experiment was conducted under natural conditions within the premises of the Laboratory of Applied Aquaculture Research (LAAR) of the Technological Institute of Boca del Río (ITBOCA).

\subsection{Collection and Identification of Macrophytes}

The collection of aquatic macrophytes Spirodela sp. and Lemna sp. was performed manually in wetlands of Medellín de Bravo, Ver., and $30 \times 30 \mathrm{~cm}$ monofilament nylon net was used. The samples were stored in plastic bags with airtight seal and transported in a cooler at room temperature, to the Research and Aquatic Resources Laboratory (RARL) of the Technological Institute of Boca del Río. The identification of species and genus was performed with an ITALY OPTICS ${ }^{\circledR}$ stereomicroscope, with the taxonomic keys described by (Rzedowski et al., 2005; Landolt \& Schmidt-Mumm, 2009; Mora-Olivo, 2013).

\subsubsection{Acclimation and Cultivation of Macrophytes}

Macrophytes Spirodela sp. and Lemna sp. were washed with drinking water and rinsed with distilled water, allowed to drain for one hour and then weighed on a CQT 202 Core balance from Adam Equipment; $200 \mathrm{~g}$ of each gender were planted in tubs of $243 \times 60.5 \times 29 \mathrm{~cm}$. The tubs were filled with effluent from $($ O. Niloticus $)$ tilapia culture in juvenile stage (30 organisms) at a level of depth of $25 \mathrm{~cm}$. The water was replaced every fifth day and $30 \%$ of the biomass was harvested each week. Acclimation and culture were for 30 days. Fish were fed three times a day with balanced food, Silver Cup ${ }^{\circledR} 3.5 \mathrm{~mm}$ (32\% protein).

\subsection{Experimental Unit}

In a geomembrane circular pond of $0.8 \times 1.5 \mathrm{~m}$ in diameter with a capacity of $4.95 \mathrm{~m}^{3}$, a semi-intensive culture of tilapia $(O$. Niloticus $)$ in growing stage (120 organisms, $\left.30 \mathrm{org} / \mathrm{m}^{3}\right)$ was maintained for 25 days. The organisms were fed three times a day, with a commercial diet of ( $5.5 \mathrm{~mm}$ Silver Cup $\left.{ }^{\circledR}\right) 32 \%$ protein. 


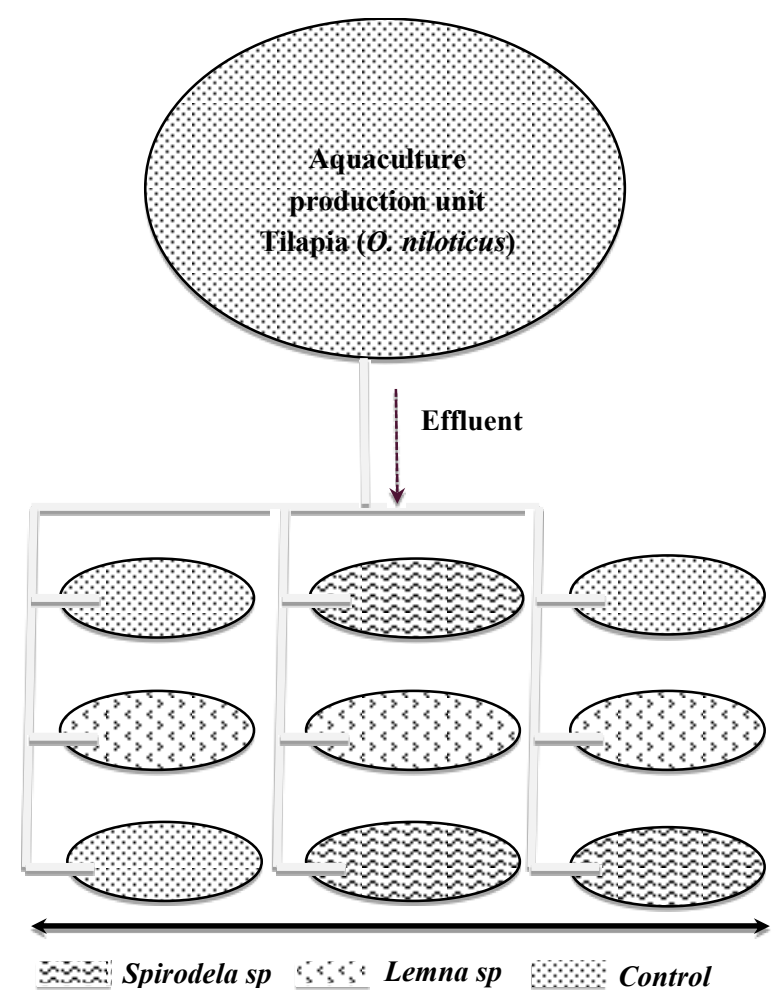

Figure 1. Experimental unit

The assessment of macrophytes for wastewater treatment consisted of three treatments in triplicate, with a control, Spirodela sp. and Lemna sp. Each treatment contained 230 liters of effluent in each tub (Figure 1) with a water sheet of $40 \mathrm{~cm}$ and a seeding density of $400 \mathrm{~g} / \mathrm{m}^{2}$ of vegetative biomass.

\subsection{Laboratory Analysis}

\subsubsection{Physico-Chemical Analysis of the Effluent}

Effluent temperature and $\mathrm{pH}$ measuring were performance in situ directly in each of the tubs (treatment and control) of the experimental system; at time 0 (effluent), 12, 24, 36, 48, 72, 96 and 120 hours. An amount of 1.5 $\mathrm{L}$ of the effluent was collected in plastic containers and taken to the laboratory for the different physico-chemical determinations. For determination of total phosphorus, $500 \mathrm{ml}$ of effluent were filtered through Whatman nitrocellulose membrane filters $\left(45 \mathrm{~mm}, 0.45 \mu \mathrm{m}\right.$ ). The remaining $1000 \mathrm{ml}$ were fixed with $\mathrm{H}_{2} \mathrm{SO}_{4}$ to get a pH less than 2. Filters and the acidified effluent were stored in refrigeration until their analysis.

Table 1. Average values of the physico-chemical characterization in the effluent

\begin{tabular}{ll}
\hline Parameter & Effluent \\
\hline $\mathrm{pH}$ & $7.4 \pm 0.00$ \\
$\mathrm{~T}\left({ }^{\circ} \mathrm{C}\right)$ & $29.0 \pm 0.00$ \\
$\mathrm{NH}_{3}-\mathrm{N}(\mathrm{mg} / \mathrm{L})$ & $4.14 \pm 0.11$ \\
$\mathrm{NO}_{2}-\mathrm{N}(\mathrm{mg} / \mathrm{L})$ & $1.0 \pm 0.00$ \\
$\mathrm{NO}_{3}-\mathrm{N}(\mathrm{mg} / \mathrm{L})$ & $10 \pm 0.00$ \\
$\mathrm{NOrg} .(\mathrm{mg} / \mathrm{L})$ & $0.93 \pm 0.17$ \\
$\mathrm{TKN}(\mathrm{mg} / \mathrm{L})$ & $5.08 \pm 0.17$ \\
Total Phosphorus $(\mathrm{mg} / \mathrm{L})$ & $0.83 \pm 0.02$ \\
\hline
\end{tabular}


The average values of the physico-chemical characterization in the effluent are shown in Table 1. Procedures corresponding to standardized methods for analysis of drinking water and wastewater were followed (APHA, 1995).

\subsubsection{Chemical Composition of Duckweeds}

Physico-chemical analyses of macrophytes were performed, in order to know the volume and composition of biomass produced. Macrophytes were harvested, weighed and dried in an oven at $60{ }^{\circ} \mathrm{C}$. Determining the chemical composition of duckweeds was performed at the end of the experiment, according to official methods of analysis of AOAC (1995).

\subsection{Assessment on Removal Efficiency}

The relation proposed by Paniagua-Michel and García (2003) (Equation 1) was used to evaluate the removal efficiency (RE), expressed as a percentage, in the different treatments.

$$
\% \mathrm{RE}=[(\text { Influent Concentration }- \text { Effluent Concentration }) / \text { Influent Concentration }] \times 100
$$

\subsection{Statistical Analysis}

The program Stadistic version 7.0 was used for analysis of variance $(p<0.05)$ and to determine significant differences between treatment and monitoring times. The test a posteriori Tukey $(\mathrm{p}<0.05)$ was applied for multiple comparisons of means.

\section{Results}

RE percentages of ammonia nitrogen $\left(\mathrm{NH}_{3}-\mathrm{N}\right)$, nitrites $\left(\mathrm{NO}_{3}-\mathrm{N}\right)$, nitrates $\left(\mathrm{NO}_{2}-\mathrm{N}\right)$ and total phosphorus $(\mathrm{TP})$, are shown in Figure 2. A maximum value of $75 \%$ removal of $\mathrm{NH}_{3}-\mathrm{N}$ with Spirodela polyrrhiza at 120 hours was observed. The removal of nitrites and nitrates was higher at $120 \mathrm{~h}, 93$ and 96\%, respectively with Spirodela polyrrhiza. The phosphorus was removed with a maximum value of $73 \%$ both at $72 \mathrm{~h}$, and at 120 hours with Spirodela polyrrhiza. 

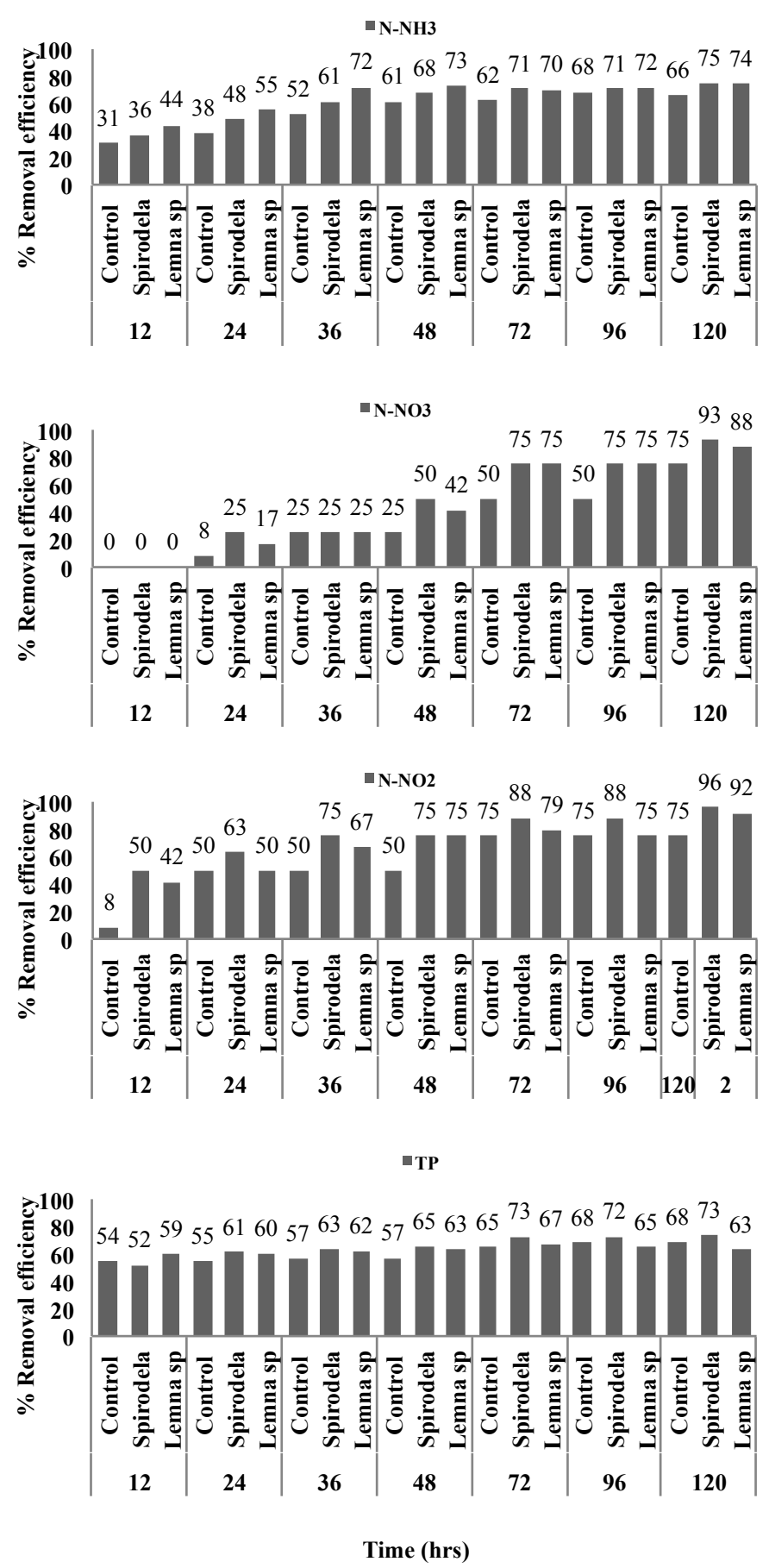

Figure 2. Nutrient removal efficiency

Some differences between the times of monitoring and treatments are observed in Figure 3, when statistical analysis is applied. 


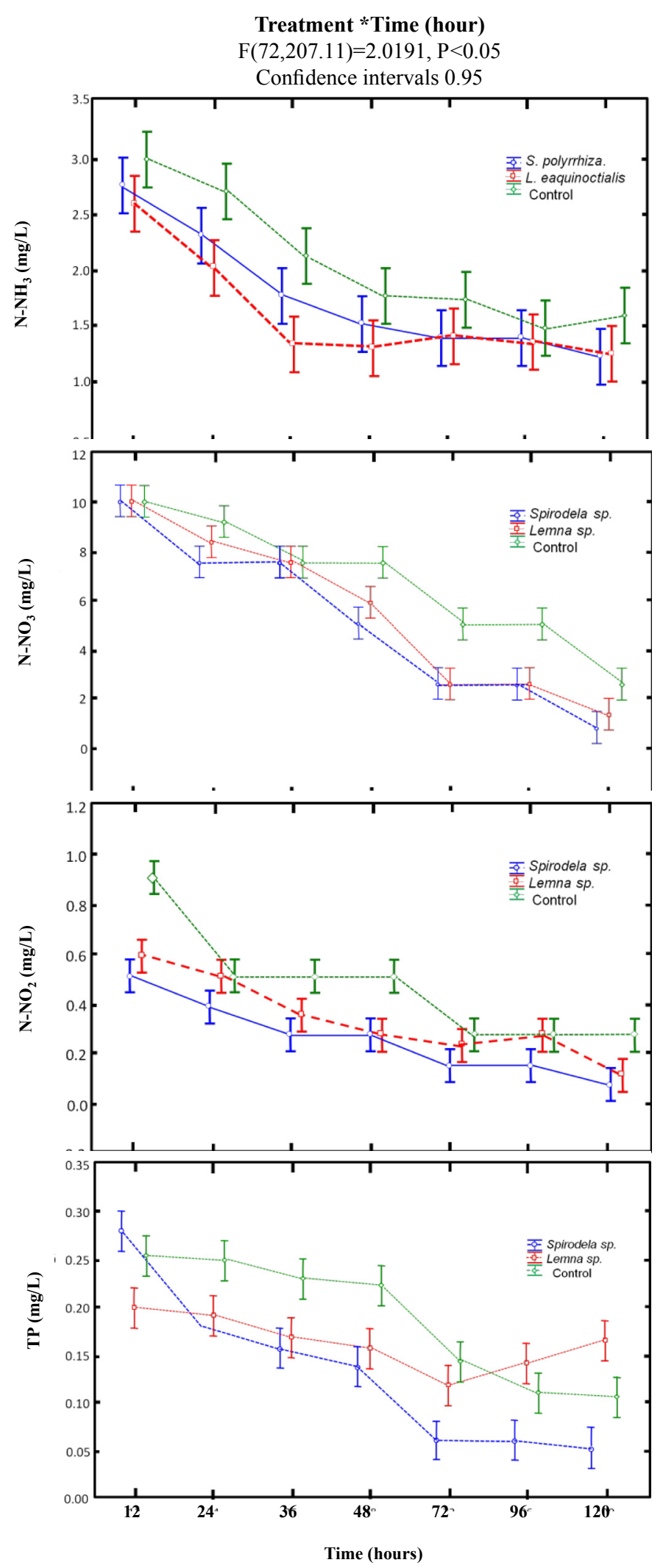

Figure 3. Analysis of variance $(\mathrm{p}<0.05)$ of $\mathrm{N}^{-\mathrm{NH}_{3}}, \mathrm{~N}-\mathrm{NO}_{2}, \mathrm{~N}_{-} \mathrm{NO}_{3}$, Total Phosphorus and control vs time 
The analysis of variance showed that there is no significant (Tukey, $\mathrm{P}<0.05$ ), with respect to monitoring times and concentrations of $\mathrm{N}-\mathrm{NH}_{3}, \mathrm{~N}-\mathrm{NO}_{2}$ and $\mathrm{N}-\mathrm{NO}_{3}$. Statistical analysis confirmed that the \% removal efficiency of $\mathrm{N}_{-} \mathrm{NH}_{3}$ was the treatment of Spirodela polyrrhiza. In the case of total phosphorus, there are significant differences between treatments and control.

Biochemical Oxygen Demand $\left(\mathrm{BOD}_{5}\right)$ decreased in the first 24 hours, 65\%, 59\%, and 33\% in treatments with Spirodela sp., Lemna sp. and control respectively. The percentage of removal of Total Suspended Solids (TSS), which decreased at $120 \mathrm{~h}$, was $83 \%, 54 \%$ and 58\%, in treatments with Spirodela sp., Lemna sp. and control respectively. The average $\mathrm{pH}$ value in the effluent was 7.4 and $7.3 \pm 0.12$ in treatments with Spirodela sp. and Lemna sp. The control treatment showed the highest variation in $\mathrm{pH}$ of $7.8 \pm 0.58$. The control treatment showed a decrease in nutrient concentration of $66 \% \mathrm{NH}_{3}-\mathrm{N}, 88 \% \mathrm{P}$, and $58 \% \mathrm{TSS}$, after five days of treatment.

The chemical composition of duckweeds, after 120 hours of treatment, is summarized in Table 2.

Table 2. Chemical composition of duckweeds

\begin{tabular}{lllll}
\hline SP & $\% \mathrm{DM}$ & $\% \mathrm{CP}$ & $\% \mathrm{~A}$ & $\% \mathrm{CF}$ \\
\hline Spirodela sp. & 92.13 & 33.91 & 15.07 & 12.46 \\
Lemna $s p$ & 95.12 & 30.10 & 10.83 & 9.45
\end{tabular}

Note. SP: Species; DM: Dry matter; CP: Crude protein; A: Ash; CF: Crude fiber.

DM content was 92 to 95\%, in macrophytes Spirodela sp. and Lemna sp., the content of CP was 34 and $30 \%$ with Lemna and Spirodela sp., in A the percentage ranged from 10.83 to 15 , and in the content of CF, values ranged from 9.45 to 12.45 with Lemna sp. and Spirodela sp., respectively.

\section{Discussion}

Waha et al. (2005) indicated that the capacity of absorption of nutrients by aquatic plants is related to the growth rate, the established population and the composition of plant tissue.

Al-Qutob and Nashashibi (2012) mentioned that duckweeds from the effluent prefer ammoniacal nitrogen as a nitrogen source and preferably will remove ammonia, even in the presence of high concentrations of nitrate. A greater efficiency than that reported by Obek and Hazar (2002) was obtained, where a removal of $90 \%$ of phosphorus was gotten with Lemna minor, which was cultivated in domestic wastewater during 6 days of treatment. The macrophyte Spirodela polyrrhiza, has been the most effective in removing nutrients. According to Brix and Schierup (1989), Oron (1994), Pardo et al. (2006), Luchini and Huidobro (2008), and Miranda (2013), aquatic macrophytes belonging to the family Lemnaceae have shown a great capacity in the assimilation of nutrients in the treatment of waste water, as can be confirmed in this study.

Mohedano (2004), worked with effluents from tilapia (O. niloticus) using Lemna valdiviana treatments and obtained removal percentages for $\mathrm{NH} 3-\mathrm{N}$ of $94.44 \%$, phosphorus $96.30 \%$, TSS $93.37 \%$, and $\mathrm{NO}_{3} 91.72 \%$, after 13 days of treatment. However, in this study similar removal rates were obtained in less time (five days).

The efficiency that these macrophytes have when assimilating nutrients is explained by Alaerts, Mahbubar, and Kelderman (1996), they mention that bacteria and algae are responsible for nitrification and denitrification of compounds dissolved in water; where duckweed (Lemna sp.) may be responsible for the removal of 16 to $47 \%$ nitrogen and 9 to $61 \%$ phosphorus. Mohedano (2004) also reported high levels of removal in control treatment of $70.36 \% \mathrm{NH}_{3}-\mathrm{N}, 63 \% \mathrm{P}$, and 70.33\% TSS, but twice as long (13 days) in effluents from tilapia.

It is noteworthy that after the third day of acclimation of Lemna sp., yellow and white fronds, and necrosis began to be observed. Mohedano (2010) reported that the rapid mortality of macrophytes may be due to high levels of toxicity of $\mathrm{NH}_{3}-\mathrm{N}$, wind, algae pollution, diseases, senescence, high density, lack of light, and $\mathrm{CO}_{2}$. Tolerances of $\mathrm{NH}_{3}-\mathrm{N}$ for tilapia culture are in the range of 0.6 to $2.0 \mathrm{mg} / \mathrm{L}$. The level of $\mathrm{NH}_{3}-\mathrm{N}$ of the effluent at the beginning of the experiment was $4.14 \mathrm{mg} / \mathrm{L}$. In this regard Abdalla, McNabb, and Batterson (1996) mentioned that tilapia (O. niloticus) can tolerate levels from 1.1 to $4.1 \mathrm{mg} / \mathrm{L}$ of $\mathrm{NH}_{3}-\mathrm{N}$ for long periods of time (up to 96 hours), showing a 50\% mortality; however, during this experiment there was a mortality of $3.3 \%$, the sensitivity of this species varies according to the size of the fish and the water temperature. Chen, Jin, Zhang, Fang, Xiao, and Zhao (2012) reported that the duckweed takes phosphorus and nitrogen from water. The nitrogen is first converted into ammonia and then taken up by the roots. For this reason, they have been used in diets for ducks, fish, and shrimp (Ponce, Febrero, González, Romero, \& Estrada, 2005). Statistical analysis applied, allowed us 
to observe that there was no significant difference between monitoring and treatment times, however in some cases it was noted that the control treatment had significant differences.

\section{Conclusions}

The efficiency of aquatic macrophytes Spirodela sp. and Lemna sp. were evaluated, which accomplished high nutrient removals. According to the results, the effluent from ponds of tilapia (O. Niloticus), can be considered an appropriate remedy to be implemented for aquatic macrophytes crops, in order to reduce nutrient concentrations that pollute the bodies of receiving water, which in turn generate biomass that can be used for feeding farmed organisms, reducing production costs. The proximate analysis performed in both macrophytes showed a high protein content and a suitable level of crude fiber, these results allow their use as aquaculture diets.

\section{References}

Abdalla, A., McNabb, C., \& Batterson, T. (1996). Ammonia dynamics in fertilized fishponds stocked with Nile Tilapia. The Progressive Fish-Culturist, 58(3), 117-123. http://dx.doi.org/10.1577/1548-8640(1996)058<01 17:ADIFFP $>2.3 . \mathrm{CO} ; 2$

Alaerts, G., Mahbubar, R., \& Kelderman, P. (1996). Performance analysis of a full-scale duckweed-covered sewage lagoon. Water Research, 30(4), 843-852. http://dx.doi.org/10.1016/0043-1354(95)00234-0

Al-Qutob, M. A., \& Nashashibi, T. S. (2012). Duckweed Lemna minor (Liliopsida, Lemnacea) as a natural biofilter in brackish and fresh closed recirculating systems. AACL BIOFLUX, 5(5), 380-392. Retrieved from https://www.researchgate.net/publication/232715627_Al-Qutob_M_A_Nashashibi_T_S_2012_Duckweed Lemna_minor_Liliopsida_Lemnaceae_as_a_natural_biofilter_in_brackish_and_fresh_closed_recirculating systems_AACL_Bioflux_55380-392

AOAC (International Association of Official Analytical Chemists). (1995). Official methods of analysis of AOAC International. AOAC, Washington, D.C.

Brix, H., \& Schierup, H. (1989). The Use of Aquatic Macrophytes in Water-pollution Control. Ambio, 18(2), 100-107. Retrieved from http://mit.biology.au.dk/ biohbn/hansbrix/pdf_files/Ambio_1989_100-107.pdf

Chen, Q., Jin, Y., Zhang, G., Fang, Y., Xiao, Y., \& Zhao, H. (2012). Improving production of bioethanol from Duckweed (Landoltia punctate) by pectinase pretreatment. Energies, 5(8), 3019-3022. http://dx.doi.org/ 10.3390/en5083019

de Waha Baillonville, T., Diara, H. F., Watanabe, I., Berthet, C., \& Van, H. (1991). Assessment and attempt to explain the high performance of Azolla in subdesertic tropics. Plant Soil, 137(1), 145-1149. http://dx.doi.org/10.1007/BF02187446

Eaton, A. D., Franson, M. A., Greenberg, A. E., \& Clesceri, L. S. (Eds.). (1995). Standard Methods for the Examination of Water and Wastewater. American Public Health Association (APHA), the American Water Works Association, and the Water Environment Federation, USA.

Espinosa, P., \& Bermúdez, M. (2012). La acuicultura y su impacto al medio ambiente (Vol. 2, pp. 221-232). Retrieved from http://www.ciad.mx/archivos/revista-dr/RES_ESP2/RES_Especial_2_10_Bermudez.pdf

Flores, J., González, E., \& Prado, P. (2007). Puntos críticos en la evaluación de impacto ambiental de la Camaronicultura en el Pacífico de Nicaragua, durante su proceso productivo: Producción de larvas, operación y abandono de Granjas. Universitas, 1(1), 33-38. http://dx.doi.org/10.5377/universitas.v1i1.1631

Food and Agriculture Organization of the United Nations. (2003). Acuicultura sostenible para el futuro. FAO. Retrieved March 23, 2016, from http://www.fao.org/spanish/newsroom/news/2003/21619-es.html

Food and Agriculture Organization of the United Nations. (2014). El estado mundial de la pesca y la acuicultura. Departamento de Pesca y Acuicultura de la FAO. Retrieved March 23, 2016, from http://www.fao.org/ fishery/sofia/es

González, R., Fonseca, E., Rico, R., Romero, O., \& Ponce, J. (2013). Utilización de Lemna trinervis en la alimentación de la tilapia aurea. Revista Granma Ciencia, 17(2), 9.

Lallana, V. (1997). Las plantas acuáticas del rio Paraná. Su importancia en el ecosistema (Artículo Técnico de divulgación AT-01). Panamá.

Landolt, E., \& Schmidt, U. (2009). Flora de Colombia. Lemnaceae (Vol. 24, p. 54). Instituto de Ciencias Naturales, Universidad Nacional de Colombia, Bogotá D. C. Colombia. 
Luchini, L., \& Huidobro, S. (2008). Perspectivas en acuicultura: Nivel mundial, regional y local (pp. 87-90). Dirección de Acuicultura-Subsecretaría de Pesca y Acuicultura. Secretaría de Agricultura, Ganadera, Pesca y Alimentos. http://produccionbovina.com.ar/produccion_peces/piscicultura/113-perspectivas.pdf

Miranda, M., \& Quiroz, A. (2013). Efecto del fotoperiodo en la remoción de plomo por Lemna Gibba L. (Lemnaceae). Polibotánica. Retrieved March 23, 2016, from http://www.redalyc.org/articulo.oa?id=62 127866010

Mohedano, A. (2010). Uso de macrófitas lemnáceas (Landoltia punctata) no polimento e valorização do efluente de suinocultura e na fixação de carbono (Doctoral dissertation). Retrieve from https://repositorio.ufsc.br/ xmlui/handle/123456789/94053

Mohedano, R. (2004). Tratamiento de efluentes y producción de alimento, en cultivos de tilapia (Oreochromis niloticus), a través de macrófitas acuáticas Lemna valdiviana (Lemnaceae). Una contribución para la sustentabilidad de la acuacultura (Dissertation). Universidad Federal de Santa Catartina, Brasil

Mora, A., Villaseñor, J., \& Martínez, M. (2013). Las plantas vasculares acuáticas estrictas y su conservación en México. Acta Botánica Mexicana, 103, 27-63. Retrieved from http://www.redalyc.org/articulo.oa?id=57425 775001

Öbek, E., \& Hasar, H. (2001). Role of duckweed (Lemna minor L.) harvesting in biological phosphate removal from secondary treatment effluents. Fresenius Environmental Bulletin, 11(1) 27-29.

Oron, G. (1994). Duckweed culture for wastewater renovation and biomass production. Agricultural Water Management, 26, 27-40. http://dx.doi.org/10.1016/0378-3774(94)90022-1

Pacheco, R. (2009). Rendimiento de la Lemna sp. Con el empleo de niveles de fertilización orgánica e inorgánica (Dissertation). Universidad de Granma, Facultad de Medicina Veterinaria. Bayamo, Provincia Granma, Cuba.

Palomarez, J. (2010). Valoración de la calidad de los influentes y efluentes de las granjas acuícolas de la cuenca baja del río Jamapa, Veracruz (Dissertation). Colegio de Postgraduados campus Veracruz. Retrieved from http://hdl.handle.net/10521/436

Paniagua, J., \& Garcia, O. (2003). Ex-situ bioremediation of shrimp culture effluent using constructed microbial mats. Aquacultural Engineering, 28, 131-139. http://dx.doi.org/10.1016/S0144-8609(03)00011-6

Pardo, S., Suárez, H., \& Soriano, E. (2006). Tratamiento de efluentes: Una vía para la acuicultura responsable. Revista MVZ Córdoba, 11(1), 20-29. Retrieved from http:/www.redalyc.org/articulo.oa?id=69309903

Ponce, J., Febrero, S., González, R., Romero, O., \& Estrada, O. (2005). Perspectivas de la Lemna sp. para la alimentación de peces. Revista Electrónica de Veterinaria, 6(3), 1-6. Retrieved from http://agris.fao.org/agris-search/search.do?recordID=DJ2012035032

Rzedowski, G., \& Rzedowski, J. (2005). Flora fanerogámica del Valle de México. Instituto de Ecología, A.C. y Comisión Nacional para el Conocimiento y Uso de la Biodiversidad, Pátzcuaro, Michoacán. Retrieved from http://www.scielo.org.mx/scielo.php?pid=S1870-34532007000200020\&script=sci_arttext

Tacon, A., \& Forster, I. (2003). Aquafeeds and the environment: Policy implications. Aquaculture, 226(1-4), 181-189. http://dx.doi.org/10.1016/S0044-8486(03)00476-9

Troell, M., Neori, A., Chopin, T., \& Buschmann, A. (2005). Biological wastewater treatment in aquaculture-More than just bacteria. World Aquaculture, 36, 27-29.

UICN (Unión Mundial para la Naturaleza). (2007). Guía para el Desarrollo Sostenible de la Acuicultura Mediterránea. Interacciones entre la Acuicultura $\mathrm{y}$ el Medio Ambiente. Retrieved from http://www.apromar.es/noticias/general/UICN-SGPM-FEAP\%20Guia-1.pdf

Zetina, C., Reta, C., Ortega, M., Ortega, E., Sánchez, M., Herrera, J., \& Becerril, M. (2010). Utilization of the duckweed (Lemnaceae) in the production of tilapia (Oreochromis spp.). Archivos de Zootecnia, 59(R), 133-155.

\section{Copyrights}

Copyright for this article is retained by the author(s), with first publication rights granted to the journal.

This is an open-access article distributed under the terms and conditions of the Creative Commons Attribution license (http://creativecommons.org/licenses/by/4.0/). 